\title{
GC-MS analysis and antibacterial activities of Moringa oleifera leaf extracts on selected clinical bacterial isolates
}

\author{
Kingsley Erhons Enerijiofi ${ }^{*} \mathbb{C}^{0}$, Funmilayo Hannah Akapo ${ }^{1}$ and Joseph Omorogiuwa Erhabor ${ }^{2,3}$
}

\begin{abstract}
Background: Man has a long history of utilizing herbal preparations to treat infections. Therefore, this study aimed to investigate the quantitative phytochemical components, gas chromatography-mass spectrometry analysis, and the antibacterial properties of the aqueous and ethanol leaf extracts of Moringa oleifera on some clinical bacterial isolates.

Results: Aqueous and ethanol extractions from Moringa oleifera yielded $40.75 \%$ and $62.87 \%$, respectively. Flavonoid ( $20.76 \mathrm{mg} / 100 \mathrm{~g}$ ) was the highest, while saponin $(2.00 \mathrm{mg} / 100 \mathrm{~g}$ ) was the least of all phytochemicals detected. The proximate nutrient composition revealed that carbohydrate (46.59\%) had the highest, while lipid (7.37\%) was the least. Eleven compounds were detected in both extracts by gas chromatography-mass spectrometry. The eleven compounds identified had higher concentrations in the ethanol extract except 2-octenoic $(26.09 \mathrm{mg} / \mathrm{kg})$ acid and 1, 2-epoxyhexadecane $(8.84 \mathrm{mg} / \mathrm{kg})$ in aqueous extract which were considerably higher than $0.62 \mathrm{mg} / \mathrm{kg}$ and $<0.01 \mathrm{mg} / \mathrm{kg}$ in ethanol extract. The minimum inhibitory concentration and minimum bactericidal concentration were $6.25 \mathrm{mg} / \mathrm{ml}$ against the test organisms for ethanol extract.
\end{abstract}

Conclusion: The antibacterial activity of the ethanol extract was more active against the bacterial isolates than the aqueous, which increased as the extract concentration increases. The reports revealed that Moringa oleifera is an allimportant herb that can inhibit infections from the studied pathogenic bacteria isolates.

Keywords: Moringa oleifera, Pharmaceutical use, Chromatography, 5-Nonanol-dibutylcarbinol, Antibacterial properties, Public health, Medicinal plant

\section{Background}

Humankind, since the advent of civilization, has relied on medicinal plants for their healing capabilities. It has been estimated that about $80 \%$ of the world's population utilizes traditional medicines as first-line drugs of choice to treat a myriad of diseases (Abalaka et al. 2012; Enerijiofi and Isola 2019). Many extracts from medicinal plants have been used for tradomedical healing purposes (Gandji et al. 2018). Additionally, herbal medicines are gaining

\footnotetext{
*Correspondence: kingsmore1luv@gmail.com; kenerijiofi@sau.edu.ng ${ }^{1}$ Department of Biological Sciences, College of Basic and Applied Sciences, Samuel Adegboyega University, Km 1, Ogwa - Ehor Road, PMB. 001, Ogwa, Edo State, Nigeria

Full list of author information is available at the end of the article
}

more ground worldwide due to the reawakened interest in the utilization of medicinal plants in sustaining human health, their origin, reduced cost, low adverse effects, little or no issue with antimicrobial resistance and bioprospecting of medicines (Enerijiofi and Isola 2019).

$M$. oleifera is a popular medicinal plant native to Africa, Asia, and America with several folkloric uses. It is a common vegetable in Eastern Nigeria, Africa. It has enjoyed series of common nomenclatures like the Horseradish tree, Drumstick tree, Ben oil tree, Miracle tree, and "Mother's Best Friend" (Fapohunda et al. 2012; Adeyemi et al. 2021). In Nigeria, it is called "Okwe Oyibo" in the Igbo language, "Zogale" among the Hausa and "Ewe Ile" in Yoruba (Mikore and Mulugeta 2017). M. oleifera is known to have immense medicinal values following its 
high concentration of vital minerals, proteins, vitamins, and $\beta$-carotene (Farooq et al. 2012). The drumstick tree is rich in natural antioxidants, extending the shelf-life of fatty foods (Abalaka et al. 2012).

The medicinal properties of this plant are linked to its antioxidant, antimicrobial and antipyretic effects of the phytochemicals (Ajayi and Fadeyi 2015; Adeyemi et al. 2021). The different parts of the Moringa tree are used in over 80 countries to support healthy living. Some of the uses of $M$. oleifera include proper functioning of the eyes, cerebral vigilance and bone strength. It is also used against malnutrition, menopause, and depression, as well as in the purification of water. The Moringa tree is used in manure and animal feed nutrient improvement and boosts milk production in lactating mothers (Deeba et al. 2015; Abd El-Hack et al. 2018). Other uses of Moringa oleifera stem from the common name-miracle tree linked to its remarkable curative potentials for different types of infirmities and certain illnesses such as influenza and catarrhal affections, nervous debility, asthma, enlarged liver and spleen, and deep-seated inflammation. (Zaku et al. 2015).

Previous studies had revealed some bioactive ingredients from different parts of the plant (Ajayi and Fadeyi 2015; Mikore and Mulugeta 2017). Atef et al. (2019) and Othman et al. (2019) reported that M. oleifera had phenol and flavonoid with varying content resulting from the different methods of extractions. They reported that steeping followed by extraction with $70 \%$ ethanol was the most viable extraction method. Other studies by Unuigbe et al. (2014) and Adeyemi et al. (2021) revealed the use of the different parts of Moringa oleifera to have potent in vitro and in vivo antioxidant activities. Also, Mangale and Chonde (2012) proved that fresh leaves extract had antimicrobial and anticancer properties. Farooq et al. (2012) showed the analgesic activity of Moringa oleifera seeds. There are little or no information on the chromatographic analyses of the Moringa oleifera leaf extracts. Hence, this study was carried out to determine via chromatographic analysis using GC-MS the phytochemical constituents of the ethanol and aqueous leaf extracts of Moringa oleifera. This study hypothesizes that Moringa oleifera extract has inhibitory activities against bacterial isolates. The antibacterial properties of the aqueous and ethanol leaf extracts of $M$. oleifera on some selected clinical bacterial isolates were also assessed.

\section{Methods}

Collection, identification, and extraction of plant material The leaves of Moringa oleifera were collected from matured healthy trees in a homestead garden at Oke-Ola in Ilaro, Ogun State, Nigeria. The leaves were removed from the branches, sorted, washed properly with sterile water to remove dirt and extraneous materials. The plant was identified by a botanist-Professor F.M. Ogbe of the Department of Biological Sciences, College of Basic and Applied Sciences, Samuel Adegboyega University, Ogwa, Edo State, Nigeria. An herbarium voucher specimen (UBH-M340) was deposited in the Herbarium of the Department of Plant Biology and Biotechnology, University of Benin, Nigeria.

The leaves of Moringa oleifera were air-dried for 12 days and then ground to a fine powder with a mortar and pestle. The large particles were removed, while the powder obtained was stored in a polythene bag before analysis.

For the aqueous extract, $45 \mathrm{~g}$ of the powdered leaves was soaked in $380 \mathrm{~mL}$ of distilled water and left to stand for $72 \mathrm{~h}$ to allow for maceration. The aqueous mixture was filtered using Whatman filter paper. For the ethanol extract, $45 \mathrm{~g}$ of the powdered leaves was soaked in $500 \mathrm{~mL}$ of ethanol and left to stand for $72 \mathrm{~h}$ to allow for maceration. The ethanol mixture was filtered using Whatman filter paper (Azwanida 2015; Nigussie et al., 2021).

\section{Qualitative and quantitative phytochemical analyses of $M$. oleifera leaf extracts}

The method of Akintelu and Amoo (2017) was used to test for alkaloids. Five grams of the powdered leaf was poured into a $250-\mathrm{mL}$ beaker followed by the addition of $200 \mathrm{~mL}$ of $10 \%$ acetic acid in ethanol and left for $4 \mathrm{~min}$ and filtered. Concentrated ammonium hydroxide was added in drops to allow for complete precipitation. The precipitate was collected, rinsed with dilute ammonium hydroxide followed by filtration. The residue was dehydrated and measured.

$$
\% \text { Alkaloid }=\frac{w_{3}-w_{2}}{w_{1}} \times 100
$$

where $\mathrm{w}_{1}=$ weight of the sample, $\mathrm{w}_{2}=$ weight of filter paper, and $w_{3}=$ weight of filter paper after drying.

The quantitative determination of flavonoids was done following outlined methods described by AOAC (2005) to test for flavonoids. A $0.5 \mathrm{~g}$ of the powdered leaf sample was placed inside a $250-\mathrm{ml}$ titration flask, followed by $100 \mathrm{ml}$ of $80 \%$ aqueous methanol. The mixture was thoroughly whirled for $4 \mathrm{~h}$ in a vortex machine. The entire mixture was filtered using a Whatman filter paper No. 42, and the entire procedure was repeated. The whole deposit was vaporized to dryness in a water bath and weighed

$$
\begin{aligned}
& \text { Flavonoids }(\mathrm{mg} / 100 \mathrm{~g}) \\
& =\frac{\text { weight of untreated sample }}{\text { weight of treated sample }} \times 100
\end{aligned}
$$

The method of Akintelu and Amoo (2017) was used to test for saponin. The powder (2 g) of the sample was poured into a $250-\mathrm{mL}$ beaker followed by $100 \mathrm{~mL}$ Isobutyl alcohol. The solution was mixed with a vortex 
machine for $5 \mathrm{~h}$ to make sure it is even and poured into a $100-\mathrm{mL}$ beaker containing $20 \mathrm{ml}$ of $40 \%$ saturated solution magnesium carbonate $\left(\mathrm{MgCO}_{3}\right)$ followed by filtration to get a colorless solution. One milliliter of the solution was emptied in a 50-ml flask followed by $2 \mathrm{ml}$ of $5 \%$ iron (III) chloride ( $\mathrm{FeCl} 3$ ) solution, and distilled water was used to make up the volume required. The solution was left for $30 \mathrm{~min}$ in other to develop color. The absorbance was read against the blank at $380 \mathrm{~nm}$.

Distilled water $(50 \mathrm{ml})$ was added to $500 \mathrm{mg}$ of powdered leaf sample in a beaker and allowed to stand on a mechanical shaker for $1 \mathrm{~h}$ to test for tannin. The sample was filtered using a Buchner funnel and Whatman No. 1 filter paper into a $50-\mathrm{mL}$ volumetric flask. Distilled water was added to the desired volume. After that, $5 \mathrm{ml}$ of the filtrate was poured into a test tube and mixed with $2 \mathrm{ml}$ of $0.1 \mathrm{M} \mathrm{FeCl}_{3}$ in $0.1 \mathrm{M}$ hydrogen chloride and $0.008 \mathrm{M}$ potassium ferrocyanide. A spectrophotometer was used to read absorbance at $420 \mathrm{~nm}$ (Fapohunda et al. 2012).

\section{Determination of proximate composition of $M$. oleifera leaf extracts}

The determination of moisture, ash, and crude fiber contents of $M$. oleifera was determined by the difference in weight before and after drying divided by the weight before drying multiplied by $100 \%$. Crude lipid content was determined by Soxhlet method. Crude protein was determined using the method of Kjeldahl flask. The sum of the percentages of the aforementioned parameters was subtracted from $100 \%$ to arrive at the carbohydrate content (AOAC 2005).

$$
\frac{\text { weight before drying-weight after drying }}{\text { weight before drying }} \times 100
$$

\section{Gas chromatography-mass spectrometry (GC-MS) analysis of $M$. oleifera leaf extracts}

Gas chromatography-mass spectrometry analysis of aqueous and ethanol extracts of Moringa. oleifera leaf extracts was done with Shimadzu Japan gas chromatography QP2010PLUS with a fused GC column (2010) and coated with polymethyl silicon $(0.25 \mathrm{~nm} \times 50 \mathrm{~m})$ with the following conditions: temperature programming from 80 to $200^{\circ} \mathrm{C}$ held at $80^{\circ} \mathrm{C}$ for $1 \mathrm{~min}$, rate $5^{\circ} \mathrm{C} /$ min and at $200^{\circ} \mathrm{C}$ for $20 \mathrm{~min}$, field ionization detector (FID) temperature $300{ }^{\circ} \mathrm{C}$, injection temperature $220^{\circ}$ $\mathrm{C}$, nitrogen at a $1 \mathrm{ml} / \mathrm{min}$ flow rate, split ratio $1: 75$. The column length is $30 \mathrm{~m}$ with a diameter of $0.25 \mathrm{~mm}$ and a flow rate of $50 \mathrm{ml} / \mathrm{min}$. The elute was emptied into a mass spectrometer with a detector voltage and sampling rate set at $1.5 \mathrm{kv}$ and $0.2 \mathrm{~s}$, respectively. The mass spectrum was connected to a computer-fed mass spectra data bank, Hermlez $233 \mathrm{M}-\mathrm{Z}$ centrifuge (Germany). The components of the extracts were preliminarily identified by corresponding peaks using Computer Wiley MS libraries and confirmed by comparison with peaks of the mass spectra in available literature (Balamurugan 2015).

\section{Tested organisms}

The test bacterial isolates (Staphylococcus aureus, Pseudomonas aeruginosa, Escherichia coli, and Salmonella species) were collected from the microbiology laboratory, Irrua Specialist Teaching Hospital, Irrua, Edo State, Nigeria. The organisms were isolated from stool samples of diarrhea patients who attended Irrua Specialist Teaching Hospital to seek medical treatment. The samples were inoculated into MacConkey agar (Becton Dickinson and Company, Cockeysville, MD, USA), blood agar and mannitol salt agar (both from HiMedia Laboratories, Mumbai, India) and incubated aerobically at $37{ }^{\circ} \mathrm{C}$, for $24 \mathrm{~h}$. After $24 \mathrm{~h}$, plates without growth were incubated further for up to $48 \mathrm{~h}$. The growth of microorganisms was identified by examining colony morphology followed by biochemical identification.

\section{Antibacterial studies}

Agar well diffusion method, as described by Erhabor (2017), was used. With the pure cultures of the test bacterial, antibacterial activity was performed to determine their respective tolerance to the extract. Sterilized agar plates were aseptically inoculated with a loopful of the test bacterial isolate. One milliliter $(1 \mathrm{ml})$ of each inoculum was introduced into the petri dish. About $15 \mathrm{ml}$ of Muller Hinton agar was poured and then swung to mix correctly and allowed to solidify. Five wells of $6 \mathrm{~mm}$ were bored with the aid of cock borer after solidification. The dry extracts were reconstituted by dissolving in $10 \%$ dimethyl sulfoxide (DMSO). In standardizing the isolates, a loopful of the stock culture of the organisms was inoculated into $5 \mathrm{ml}$ sterile nutrient broth and incubated for $24 \mathrm{~h}$. The broth culture of the organisms $(0.2 \mathrm{ml})$ was inoculated into $20 \mathrm{ml}$ of sterile nutrient broth and incubated for 3-5 h. The turbidity of the culture was compared with that of $0.5 \mathrm{Mac}$-Farland to standardize the culture to $10^{6} \mathrm{cfu} / \mathrm{ml}$. Then, a volume of $0.2 \mathrm{ml}$ of the reconstituted extract at the tested concentrations was dispensed into the wells. The commercial standard antibiotics discs were used as positive control. The plates were allowed to stand for $30 \mathrm{~min}$ for pre-diffusion of the extract to occur and then incubated at $37^{\circ} \mathrm{C}$ for $24 \mathrm{~h}$. The efficiency of the extracts was carried out by measuring the diameter zone of inhibition around the well $(\mathrm{mm})$. The mean of triplicate results was taken.

The following concentrations: $50 \mathrm{mg} / \mathrm{ml}, 25 \mathrm{mg} / \mathrm{ml}$, $12.5 \mathrm{mg} / \mathrm{ml}$ and $6.25 \mathrm{mg} / \mathrm{ml}$ were used to determine the 
MIC of the leaf extracts. A sterile cotton wool swab was used to inoculate pure cultures on nutrient agar plates and allowed to dry, followed by boring wells $(6 \mathrm{~mm})$ with a sterilized cork borer. After that, $100 \mu \mathrm{L}$ aliquots of the different concentrations of both leaf extracts were transferred into labeled wells. The plates were incubated at $37^{\circ} \mathrm{C}$ for $24 \mathrm{~h}$ and, after that, observed for bacterial growth or not. The lowest of all concentrations that failed to give bacterial growth was recorded as the MIC. For the determination of $\mathrm{MBC}$, the concentration that failed to give bacterial growth (MIC) was sub-cultured on the surface nutrient agar, followed by incubation at $37^{\circ} \mathrm{C}$ for $24 \mathrm{~h}$. The lowest concentration that failed to grow after $24 \mathrm{~h}$ of incubation was taken as the MBC (Enerijiofi and Isola 2019).

\section{Analysis data}

Data were presented as mean $\pm \mathrm{SEM}$ of the respective triplicate. One-way ANOVA was done to compare the means of the groups and Duncan's multiple range tests to analyze differences among different means. Differences at $p<0.05$ were statistically significant. SPSS software was used for the analysis (Ogbeibu 2005).

\section{Results}

The ethanol extract gave a higher yield than the aqueous extract of the Moringa oleifera leaves, with $62.87 \%$ and $40.75 \%$, respectively. This means that ethanol was a better extracting solvent than aqueous extract, as shown in Table 1 . The quantitative analyses of the phytochemicals per $100 \mathrm{~g}$ are recorded in Table 2. Flavonoid $(20.76 \pm 0.11 \mathrm{mg})$ was the highest, followed by tannin $(11.64 \pm 0.14 \mathrm{mg})$ and least in saponin $(2.00 \pm 0.21 \mathrm{mg})$.

The proximate nutrient composition is recorded in Table 3. Carbohydrate $(46.59 \pm 0.02 \%)$ was the highest nutrient recorded, followed by crude protein $(11.96 \pm 0.21 \%)$, Ash (11.21 $\pm 0.59 \%)$, moisture content $(11.80 \pm 0.34 \%)$, crude fiber $(11.07 \pm 0.13 \%)$ and least in crude lipid $(7.37 \pm 0.19 \%)$.

Eleven compounds were detected by their retention time and molecular formula in both extracts of the leaf by gas chromatography-mass spectrometry as recorded in Table 4 and Figs. 1 and 2. The compounds identified included: 5-nonanol-dibutylcarbinol,

Table 1 Percentage yield and physical characteristics of the aqueous and ethanol extracts of Moringa oleifera leaf

\begin{tabular}{lllll}
\hline Extracts & $\begin{array}{l}\text { Powdered } \\
\text { leaf material } \\
\text { (g) }\end{array}$ & Yield in (g) & Yield in (\%) & $\begin{array}{l}\text { Physical } \\
\text { characteristics }\end{array}$ \\
\hline Aqueous & 45 & 18.34 & 40.75 & Black \\
Ethanol & 45 & 28.29 & 62.87 & Light green \\
\hline
\end{tabular}

Table 2 Quantitative determination of phytochemicals from aqueous and ethanol extracts of $M$. oleifera leaf powder

\begin{tabular}{lll}
\hline $\begin{array}{l}\text { Phytochemical } \\
\text { constituents }\end{array}$ & $\begin{array}{l}\text { Ethanol concentrations } \\
\text { (mg/100 g) }\end{array}$ & $\begin{array}{l}\text { Aqueous } \\
\text { concentrations } \\
\text { (mg/100 g) }\end{array}$ \\
\hline Alkaloid & $4.5 \pm 0.02$ & $1.11 \pm 2.11$ \\
Flavonoid & $20.76 \pm 0.11$ & $2.21 \pm 1.22$ \\
Saponin & $2.00 \pm 0.21$ & $0.10 \pm 2.01$ \\
Tannin & $11.64 \pm 0.14$ & $1.10 \pm 1.31$ \\
\hline
\end{tabular}

Values are the mean \pm SEM of 3 replicates

5-hydroxyl-2-(hydroxyl methyl)-4H-pyran-4-one, 2-octenoic acid, 1-hydroxyl- 2,2,6,6-tetramethyl-3-(4-nitroso1-piperazinylmethyl)-piperidine-4-one, tetradecanoic acid, pentadecanoic acid, 1, 2-epoxyhexadecane (oxirane), hexadecanoic acid, 6-octadecenoic acid, 1, 2-benzene dicarboxylic and 11-bromoundecanoic acid. The eleven compounds identified had higher concentration in the ethanol extract except 2-octenoic $(26.09 \mathrm{mg} / \mathrm{kg})$ acid and 1 , 2-epoxyhexadecane $(8.84 \mathrm{mg} / \mathrm{kg})$ in aqueous extract which were far higher than $0.62 \mathrm{mg} / \mathrm{kg}$ and $<0.01 \mathrm{mg} / \mathrm{kg}$ in ethanol extract.

The antibacterial activity of Moringa oleifera leaf extracts is presented in Table 5. Ethanol extract had the highest zone of inhibition at $200 \mathrm{mg} / \mathrm{ml}$ of $23 \pm 0.02 \mathrm{~mm}$ for Staphylococcus aureus, $25 \pm 0.51$ for Pseudomonas aeruginosa, $22 \pm 0.48 \mathrm{~mm}$ for Escherichia coli and $28 \pm 0.34 \mathrm{~mm}$ for Salmonella sp. Aqueous extract at $200 \mathrm{mg} / \mathrm{ml}$ gave $6 \pm 0.01 \mathrm{~mm}$ for Staphylococcus aureus, $5 \pm 0.11 \mathrm{~mm}$ for Pseudomonas aeruginosa, $8 \pm 0.25 \mathrm{~mm}$ for Escherichia coli, and $5 \pm 0.14 \mathrm{~mm}$ for Salmonella species.

Table 6 shows the minimum inhibitory concentrations obtained for aqueous and ethanol extracts. The least ethanol concentration of $6.25 \mathrm{mg} / \mathrm{ml}$ inhibited bacterial growth as against the aqueous extract.

The results for the minimum bactericidal concentration of the aqueous and ethanol extracts are presented in

Table 3 Proximate analysis of aqueous and ethanol extracts of M. oleifera leaf powder

\begin{tabular}{lll}
\hline Parameters & Yield on ethanol extract & $\begin{array}{l}\text { Yield on } \\
\text { aqueous } \\
\text { extract }\end{array}$ \\
\hline Moisture content & $11.80 \pm 0.34$ & $0.11 \pm 1.11$ \\
Ash content & $11.21 \pm 0.59$ & $1.23 \pm 0.56$ \\
Crude fiber & $11.07 \pm 0.13$ & $2.11 \pm 0.24$ \\
Crude lipid & $7.37 \pm 0.19$ & $1.22 \pm 0.51$ \\
Crude protein & $11.96 \pm 0.21$ & $3.06 \pm 0.74$ \\
Carbohydrates & $46.59 \pm 0.02$ & $4.32 \pm 0.62$ \\
\hline
\end{tabular}


Table 4 Phytochemical components identified in aqueous and ethanol extracts of Moringa oleifera leaves by GC-MS analysis

\begin{tabular}{|c|c|c|c|c|c|c|c|}
\hline Name of compound & Molecular formula & $\begin{array}{l}\text { RT } \\
\text { water } \\
\text { extract }\end{array}$ & $\mathrm{mg} / \mathrm{kg}$ & $\begin{array}{l}\text { RT } \\
\text { ethanol } \\
\text { extract }\end{array}$ & $\mathrm{mg} / \mathrm{kg}$ & $\begin{array}{l}\text { Recorded } \\
\text { pharmacological activity }\end{array}$ & References \\
\hline 5-Nonanol-dibutylcarbinol & $\mathrm{C}_{9} \mathrm{H}_{20} \mathrm{O}$ & 3.2 & 3.25 & 3.2 & 44.32 & - & \\
\hline $\begin{array}{l}\text { 5-hydroxy-2-(hydroxyl } \\
\text { methyl)-4H-pyran-4-one }\end{array}$ & $\mathrm{C}_{6} \mathrm{H}_{6} \mathrm{O}_{4}$ & 9.1 & 2.54 & 7.3 & 35.89 & - & \\
\hline 2-octenoic acid & $\mathrm{C}_{8} \mathrm{H}_{14} \mathrm{O}_{2}$ & 14.3 & 26.08 & 9.7 & 0.62 & - & \\
\hline $\begin{array}{l}\text { 1-hydroxy-2,2,6,6-tetra- } \\
\text { methyl-3- (4-nitroso-1- } \\
\text { (piperazinylmethyl)-piperi- } \\
\text { din-4-one }\end{array}$ & $\mathrm{C}_{14} \mathrm{H}_{26} \mathrm{~N}_{4} \mathrm{O}_{3}$ & 15.2 & 5.14 & 15.1 & 30.01 & - & \\
\hline Tetradecanoic acid & $\mathrm{C}_{14} \mathrm{H}_{22} \mathrm{O}_{2}$ & ND & $<0.001$ & 15.6 & 10.64 & $\begin{array}{l}\text { Larvicidal and repellent } \\
\text { activity, antifungal, anti- } \\
\text { oxidant, cancer preventive, } \\
\text { nematicide, hypercholes- } \\
\text { terolemic }\end{array}$ & Sivakumar et al. 2011 \\
\hline Pentadecanoic acid & $\mathrm{C}_{15} \mathrm{H}_{30} \mathrm{O}_{2}$ & 16.4 & $<0.001$ & 19.6 & 22.19 & Antimicrobial & Mujeeb et al. 2014 \\
\hline $\begin{array}{l}\text { 1, 2-epoxyhexadecane } \\
\text { (oxirane) }\end{array}$ & $\mathrm{C}_{16} \mathrm{H}_{32} \mathrm{O}$ & 18.4 & 8.84 & ND & $<0.001$ & - & \\
\hline Hexadecanoic acid & $\mathrm{C}_{16} \mathrm{H}_{32} \mathrm{O}_{2}$ & ND & $<0.001$ & ND & $<0.001$ & $\begin{array}{l}\text { Antioxidant, hypocho- } \\
\text { lesterolemic nematicide, } \\
\text { pesticide, antiandrogenic } \\
\text { flavor, hemolytic, 5-alpha } \\
\text { reductase inhibitor, anti- } \\
\text { microbial }\end{array}$ & $\begin{array}{l}\text { Chandrasekaran et al. 2011; } \\
\text { Mujeeb et al. } 2014\end{array}$ \\
\hline 6-octadecenoic acid & $\mathrm{C}_{18} \mathrm{H}_{34} \mathrm{O}_{2}$ & ND & $<0.001$ & 22.9 & 9.07 & $\begin{array}{l}\text { Antifungal, antibacterial, } \\
\text { analgesic, anti-inflamma- } \\
\text { tory and antipyretic }\end{array}$ & $\begin{array}{l}\text { Mujeeb et al. 2014, Jaddoa } \\
\text { et al. } 2016\end{array}$ \\
\hline $\begin{array}{l}\text { 1,2-Benzenedicarboxylic } \\
\text { acid }\end{array}$ & $\mathrm{C}_{8} \mathrm{H}_{6} \mathrm{O}_{4}$ & ND & $<0.001$ & 28.6 & 19.38 & Antimicrobial, antifouling & Sivakumar et al. 2011 \\
\hline 11-bromoundecanoic acid & $\mathrm{C}_{11} \mathrm{H}_{21} \mathrm{BrO}_{2}$ & 38.7 & 19.89 & 31.3 & 27.46 & - & \\
\hline
\end{tabular}

Table 7. The results revealed that the least ethanol concentration of $6.25 \mathrm{mg} / \mathrm{ml}$ was bactericidal to bacterial growth as against the aqueous extract.

\section{Discussion}

The ethanol extract gave more yield than the aqueous extract. This probably infers that ethanol had better solubility, extracting and quantitative abilities of the active components from Moringa oleifera leaves than water. Earlier studies by Enerijiofi and Isola (2019) and Singa et al. (2021) reported that ethanol extracts had better antibacterial activity than aqueous extracts of plants extracts. This study reported phytochemicals such as flavonoids, tannins, saponins, and alkaloids; meanwhile, phytochemicals such as flavonoids, saponins, and tannins had earlier been reported as antibacterial agents (Adetitun et al. 2013; Unuigbe et al. 2014; Oyama et al. 2019). Flavonoids had the highest percentage composition, which may be responsible for the antioxidant, anticancer and other properties of the plant. Tannins were also recorded, and it is known as a major constituent that is harsh and is used in the management of intestinal disorders like diarrhea and dysentery, demonstrating antimicrobial action (Alhakmni et al. 2013). These phytochemicals can be used to discover novel therapeutic drugs with improved efficiency.

The result showed that the studied extracts are rich in the six classes of food, making the consumers healthy. However, this report agreed with the findings of Ajayi and Fadeyi (2015) in Akungba Akoko where they also reported ash content $(11.78 \%)$, moisture content $(9.00 \%)$, crude protein (12.67\%), crude lipid (6.34\%), fiber (12.45\%) and carbohydrate $(45.92 \%)$. Also, (24) on proximate composition of Moringa oleifera leaf reported moisture content (6.60\%), ash content (15.6\%), crude fiber (6.13\%), crude lipid (7.35\%), crude protein (24.3\%) and carbohydrate $(40.02 \%)$. Carbohydrates had the highest concentration, meaning that the leaf is rich in energy. Also, high protein and fiber contents recorded points that leaf supports growth and aid digestion of food, respectively, as reported earlier (Teixeira et al. 2014; Nigussie et al. 2021; Singa et al. 2021).

Studies of organic compounds from plants and their activities are increasing, mainly as they are storehouses for novel drugs. Gas chromatography-mass spectrometry $(\mathrm{GC}-\mathrm{MS})$ has proven to be a valuable tool for the 


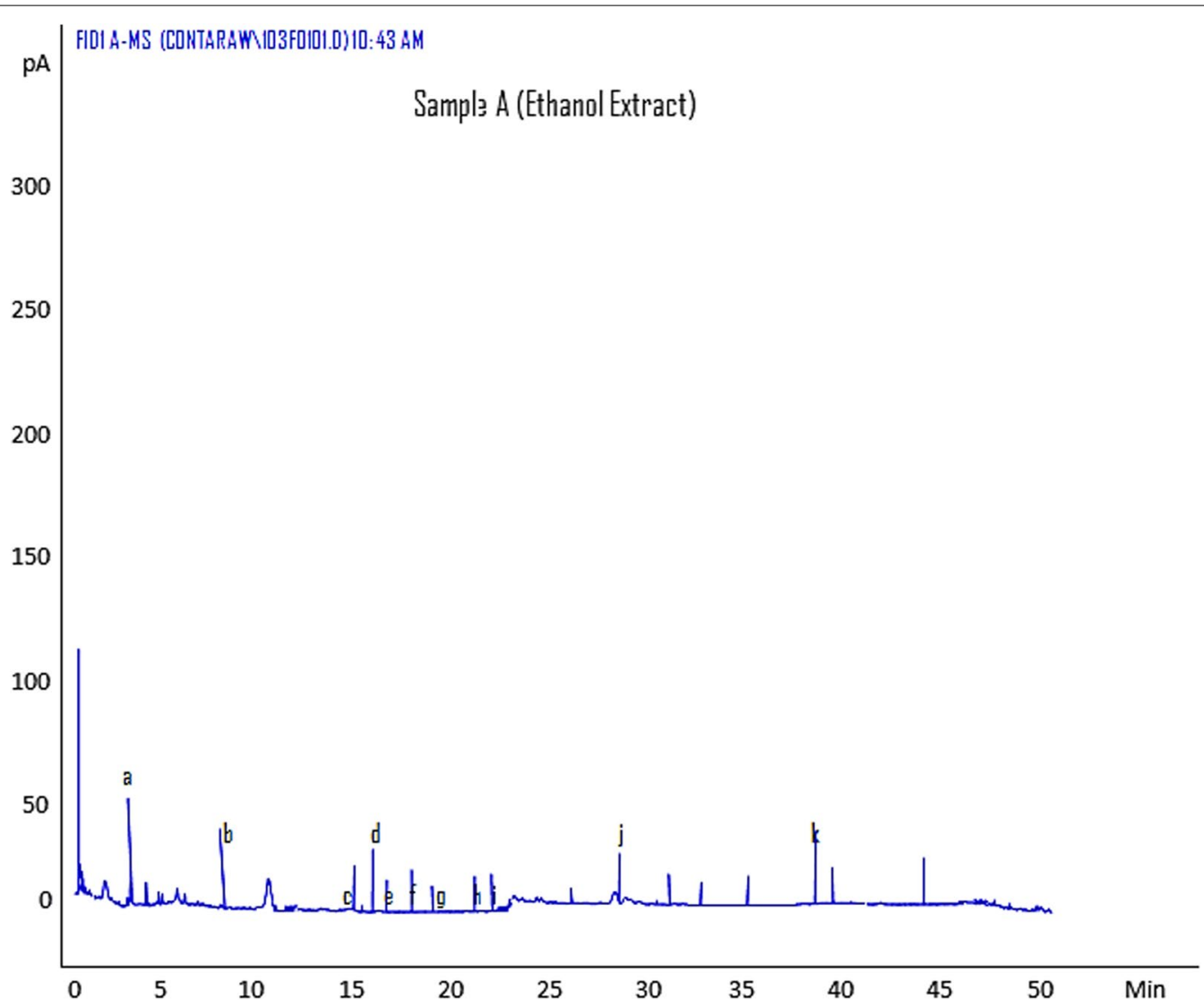

Fig. 1 Gas chromatography-mass spectroscopy chromatogram of Moringa oleifera leaf ethanol extract

dependable identification of bioactive components in plant studies (Balamurugan et al. 2015). However, some of the identified compounds were similar to the ones earlier documented by Azwanida (2015): butanoic acid, 1,5-heptadiene, 3,3, dimethyl-(E) and 2-propanoic acid, 2 propanyl ester in leaf and Squalene, 1-hexanol, 2-ethyl2-propyl, 1, 2-benzenedicarboxylic acid, hexanedioic acid, heptane, heptanoic acid, and isooctanol from the bark of Moringa concanensis. These organic compounds identified could be accountable for the antimicrobial, anti-cancer, analgesic, hepatoprotective and anti-inflammatory properties which supports its wide use as health aid by tradomedical practitioners (Farooq et al. 2012; Vongsak et al. 2013; Husni et al. 2021). However, Abd ElHack et al. (2018) and Husni et al. (2021) gave credence to the findings of this study when they reported that organic solvents like methanol extracts of parts of Moringa oleifera exhibited strong in vitro and in vivo antioxidant activities.

This study reported that both leaf extracts had antibacterial activity on all the isolates. However, ethanol extracts displayed better antibacterial activity than aqueous extracts. This implied that the antibacterial components were more inherent in the alcohol concentrations than aqueous (Ajayi and Fadeyi 2015; Singa et al. 2021). Also, the extracts' antibacterial efficacy, particularly ethanol, was observed to increase as the concentrations of the plant extract increases. Also, Bukar et al. (2010) reported the ethanol extracts of Moringa oleifera leaf had the broadest spectrum of activity on the test bacterial isolates. Of the commercially available standard antibiotics (positive control), augmentin $(30 \mu \mathrm{g})$ gave the best activity with a zone of inhibition of $27 \mathrm{~mm}$ against Escherichia coli. S. aureus showed susceptibility to CPX: ciprofloxacin $(10 \mu \mathrm{g})$, PEF: pefloxacin $(30 \mu \mathrm{g}), \mathrm{S}$ : streptomycin, SXT: septrin $(30 \mu \mathrm{g})$, GN: gentamycin $(10 \mu \mathrm{g})$ and $\mathrm{R}$ : rocephin $(25 \mu \mathrm{g})$ within a range of zone of inhibition between 12 and $18 \mathrm{~mm}$ like the ethanol extract of $M$. oleifera within the concentrations $(6.25-100 \mathrm{mg} / \mathrm{ml}) \mathrm{uti}$ lized in the study.

Interestingly, $S$. aureus was resistant to some of the standard antibiotics (APX: ampiclox $(30 \mu \mathrm{g}), \mathrm{Z}$ : zinacef $(20 \mu \mathrm{g}), \mathrm{AM}$ : amoxicillin $(30 \mu \mathrm{g})$ and $\mathrm{E}$ : erythromycin $(10 \mu \mathrm{g}))$ which was similar to its resistance to the aqueous extract across the tested concentrations (Tables 6 and 7). $P$. aeruginosa displayed no susceptibility to the standard 


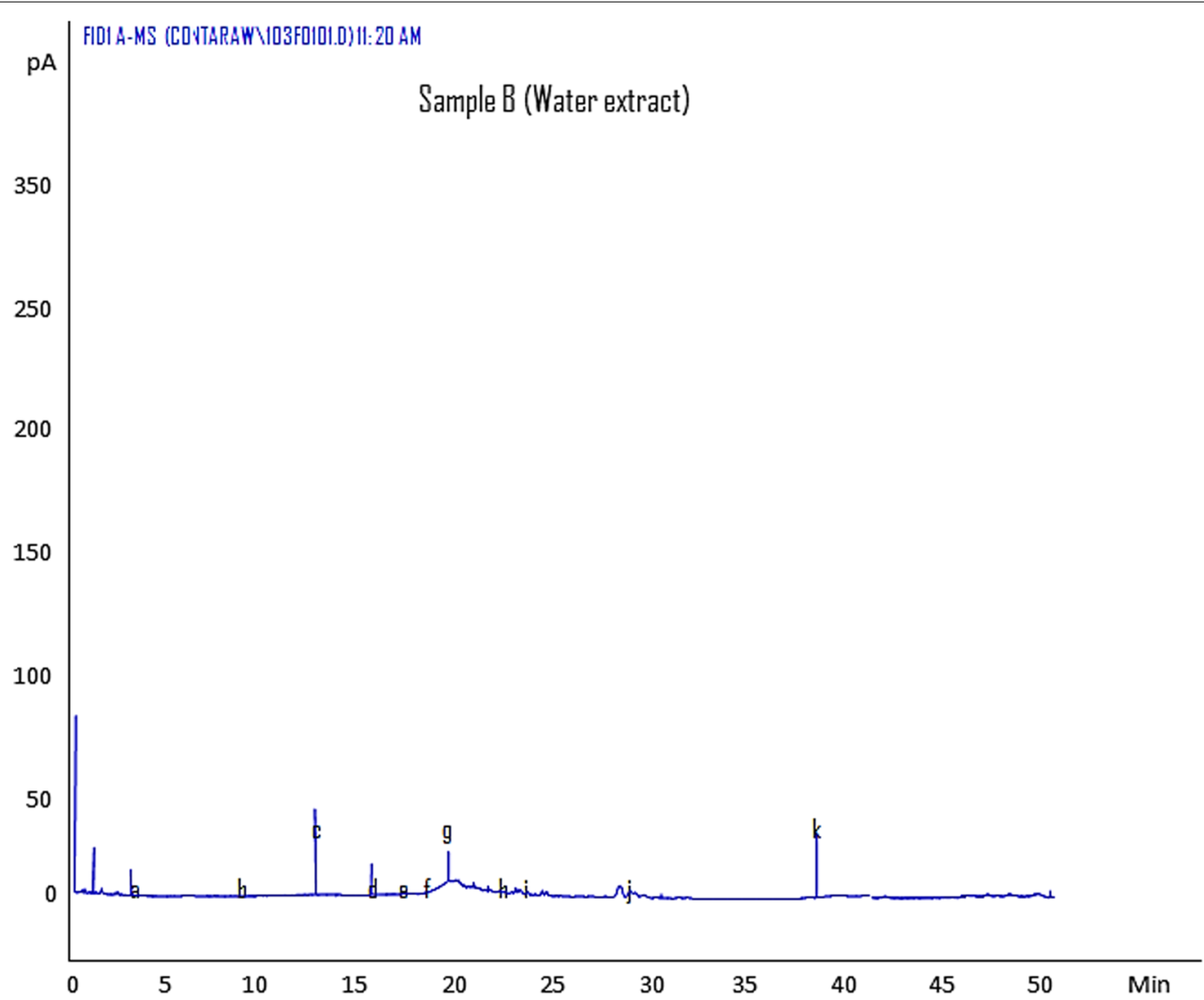

Fig. 2 Gas chromatography-mass spectroscopy chromatogram of Moringa oleifera leaf aqueous extract

Table 5 Antibacterial activity of Moringa oleifera extracts on bacterial isolates

\begin{tabular}{|c|c|c|c|c|c|c|c|c|}
\hline \multirow[t]{2}{*}{ Test organisms } & \multicolumn{4}{|c|}{$\begin{array}{l}\text { Aqueous extract concentration } \\
(\mathrm{mg} / \mathrm{ml})\end{array}$} & \multicolumn{4}{|c|}{$\begin{array}{l}\text { Ethanol extract concentration } \\
(\mathrm{mg} / \mathrm{ml})\end{array}$} \\
\hline & 200 & 100 & 50 & 25 & 200 & 100 & 50 & 25 \\
\hline S. aureus & ${ }^{\mathrm{a}} 6 \pm 0.01$ & ${ }^{a} 5 \pm 0.34$ & ${ }^{\mathrm{a}} 4 \pm 0.17$ & $a_{3} \pm 0.02$ & ${ }^{\mathrm{a}} 23 \pm 0.02$ & $b_{17} \pm 0.32$ & ${ }^{b} 15 \pm 0.11$ & ${ }^{b} 12 \pm 0.21$ \\
\hline P.. aeruginosa & ${ }^{a} 5 \pm 0.11$ & ${ }^{\mathrm{a}} 4 \pm 0.22$ & ${ }^{a} 3 \pm 0.23$ & ${ }^{\mathrm{a}} 2 \pm 0.15$ & ${ }^{\mathrm{a}} 25 \pm 0.51$ & ${ }^{b} 21 \pm 0.20$ & ${ }^{c} 17 \pm 0.34$ & ${ }^{d} 13 \pm 0.16$ \\
\hline Escherichia coli & ${ }^{\mathrm{a}} 8 \pm 0.25$ & ${ }^{\mathrm{a}} 4 \pm 0.32$ & ${ }^{\mathrm{a}} 4 \pm 0.13$ & ${ }^{\mathrm{a}} 4 \pm 0.29$ & ${ }^{\mathrm{a}} 22 \pm 0.48$ & ${ }^{b} 16 \pm 0.19$ & ${ }^{b} 14 \pm 0.29$ & ${ }^{c} 10 \pm 0.32$ \\
\hline Salmonella sp. & $a_{5} \pm 0.14$ & ${ }^{a} 5 \pm 0.19$ & ${ }^{\mathrm{a}} 4 \pm 0.07$ & $\mathrm{a}_{3} \pm 0.14$ & ${ }^{\mathrm{a}} 28 \pm 0.34$ & ${ }^{b} 21 \pm 0.24$ & ${ }^{b} 19 \pm 0.26$ & ${ }^{c} 12 \pm 0.32$ \\
\hline Control (water) & $\mathrm{NZI}$ & $\mathrm{NZI}$ & $\mathrm{NZI}$ & $\mathrm{NZI}$ & $\mathrm{NZI}$ & $\mathrm{NZI}$ & $\mathrm{NZI}$ & $\mathrm{NZI}$ \\
\hline
\end{tabular}

Table 6 Minimum inhibitory concentrations $(\mathrm{mg} / \mathrm{ml})$ of aqueous and ethanol extracts of Moringa oleifera leaf

\begin{tabular}{lllllllll}
\hline Test organisms & \multicolumn{3}{l}{ Aqueous extract } & & \multicolumn{3}{l}{ Ethanol extract } \\
\cline { 2 - 9 } & $\mathbf{5 0}$ & $\mathbf{2 5}$ & $\mathbf{1 2 . 5}$ & $\mathbf{6 . 2 5}$ & & $\mathbf{5 0}$ & $\mathbf{2 5}$ & $\mathbf{1 2 . 5}$ \\
\hline Staphylococcus aureus & + & + & + & + & - & - & - \\
Pseudomonas aeruginosa & + & + & + & + & - & - & - \\
Escherichia coli & + & + & + & + & - & - & - & - \\
Salmonella species & + & + & + & + & - & - & - \\
\hline
\end{tabular}


Table 7 Minimum bactericidal concentration (MBC) in $\mathrm{mg} / \mathrm{ml}$ of aqueous and ethanol extract of Moringa oleifera leaf

\begin{tabular}{lllllllll}
\hline Test organisms & \multicolumn{3}{l}{ Aqueous extract } & & \multicolumn{3}{c}{ Ethanol extract } \\
\cline { 2 - 9 } & $\mathbf{5 0}$ & $\mathbf{2 5}$ & $\mathbf{1 2 . 5}$ & $\mathbf{6 . 2 5}$ & & $\mathbf{5 0}$ & $\mathbf{2 5}$ & $\mathbf{1 2 . 5}$ \\
\hline Staphylococcus aureus & + & + & + & + & - & - & - \\
Pseudomonas aeruginosa & + & + & + & + & - & - & - \\
Escherichia. coli & + & + & + & + & - & - & - \\
Salmonella sp. & + & + & + & + & - & - & - \\
\hline
\end{tabular}

Table 8 Zone of inhibition ( $\mathrm{mm}$ ) for antibiotics susceptibility test

\begin{tabular}{|c|c|c|c|c|c|c|c|c|c|c|}
\hline Gram positive & CPX & PEF & $S$ & SXT & GN & APX & $z$ & $A M$ & $\mathbf{R}$ & $\mathrm{E}$ \\
\hline S. aureus & 17 & 15 & 14 & 14 & 18 & NMZI & NMZI & NMZI & 12 & NMZI \\
\hline Gram-negative & SXT & $\mathrm{CH}$ & SP & CPX & $A M$ & $A U$ & $\mathrm{CN}$ & PEF & OFX & $S$ \\
\hline Pseudomonas aeruginosa & NMZI & NMZI & $\mathrm{NMZI}$ & NMZI & NMZI & NMZI & NMZI & $\mathrm{NMZI}$ & NMZI & NMZI \\
\hline Escherichia coli & 19 & NMZI & NMZI & 15 & NMZI & 27 & 17 & NMZI & $\mathrm{NMZI}$ & NMZI \\
\hline Salmonella species & NMZI & 12 & $\mathrm{NMZI}$ & 21 & NMZI & 18 & $\mathrm{NMZI}$ & $\mathrm{NMZI}$ & NMZI & 19 \\
\hline
\end{tabular}

antibiotics, and this was dissimilar to the ethanol extract of $M$. oleifera with strong inhibitory activity against it (Tables 5, 6 and 7). E. coli and Salmonella sp showed selective susceptibility and resistance against the standard antibiotics similar to the earlier trend of susceptibility and resistance to the ethanol and aqueous extracts of $M$. oleifera (Tables 6 and 7).

This study agreed with Ajayi and Fadeyi (2015) earlier submissions, which reported that aqueous extracts of plants usually display little or no antimicrobial activity. In collaboration, Moyo et al. (2012) reported that aqueous extracts differed from other extracting solvents due to the availability of several compounds that may interact antagonistically in their overall activities. Statistically, the inhibitory activity of the ethanol extract at $200 \mathrm{mg} /$ $\mathrm{ml}$ was significantly different from the other concentrations (100, 50 and $25 \mathrm{mg} / \mathrm{ml}$ ) against Staphylococcus aureus. At the same time, there was a significant difference in the inhibitory activities at all concentrations against Pseudomonas aeruginosa. Also, there was a significant difference in the inhibitory activities at $200 \mathrm{mg} /$ $\mathrm{ml}$ and $25 \mathrm{mg} / \mathrm{ml}$ for Escherichia coli and Salmonella species compared to other concentrations. However, it was generally observed that there were significant differences in the inhibitory activities of ethanol extract at all tested concentrations against the isolated organisms $(\mathrm{p}<0.05)$, which was not the case with aqueous extract.

The results of the aqueous extract showed all bacterial isolates in this study were utterly resistant at all concentrations. However, the ethanol extract with a minimum inhibitory concentration of $6.25 \mathrm{mg} / \mathrm{ml}$ prevented the growth of Staphylococcus aureus, Pseudomonas aeruginosa, Escherichia coli and Salmonella species in visually clear zones after $24 \mathrm{~h}$ of incubation. However, ethanol extract had good antibacterial activity against all the bacterial isolates tested, as reported earlier by (Unuigbe et al. 2014; Singa et al. 2021). It could also result from other compounds that may act in opposite ways for the overall activities, as reported earlier by Moyo (2012) in South Africa. The findings in this study corroborate with earlier reports from previous researchers (Jaiswal et al. 2013; Ajayi and Fadeyi 2015 and Atef 2019), where they reported alcohol and aqueous leaves extracts of Moringa oleifera as antimicrobial, anti-cancer, analgesic, hepatoprotective, antioxidant and anti-inflammatory agent. The result corroborates the use of the plant extracts traditionally as an antimicrobial agent since it relieves gastrointestinal tracts irritations (Erhabor et al. 2017). This could be traced to the lack of specific concentrations during administration by herbal medicine practitioners which account for the intake of large quantities of the extracts by their patients. Antibiotic susceptibility test revealed that the most active standard antibiotic was augmentin with a zone of inhibition measuring $27 \mathrm{~mm}$ against Escherichia coli.

In contrast, the least active standard antibiotics were pefloxacin and rocephin, which all recorded the zone of inhibition of $12 \mathrm{~mm}$ (Table 8). Zhang et al. (2018) observed that the susceptibility of gram-positive bacteria isolates to erythromycin, methicillin and vancomycin was 
generally high, while that to bacitracin and novobiocin was low. This suggests that the penicillinase-resistant antibacterial agents should be selected as a first choice to treat these infections.

\section{Conclusions}

The study revealed that Moringa oleifera leaves are rich in phytochemicals and antimicrobials. Also, this study revealed that ethanol extract was a better extracting solvent and showed better inhibitory activity against the bacterial isolates. Ethanol extract had the highest zone of inhibition at $200 \mathrm{mg} / \mathrm{ml}$ of $23 \pm 0.02 \mathrm{~mm}$ for Staphylococcus aureus, $25 \pm 0.51$ for Pseudomonas aeruginosa, $22 \pm 0.48 \mathrm{~mm}$ for Escherichia coli and $28 \pm 0.34 \mathrm{~mm}$ for Salmonella sp. Aqueous extract at $200 \mathrm{mg} / \mathrm{ml}$ gave $6 \pm 0.01 \mathrm{~mm}$ for Staphylococcus aureus, $5 \pm 0.11 \mathrm{~mm}$ for Pseudomonas aeruginosa, $8 \pm 0.25 \mathrm{~mm}$ for Escherichia coli, and $5 \pm 0.14 \mathrm{~mm}$ for Salmonella species. This may justify its use by the world's population in treating gastrointestinal irritations arising from pathogenic bacteria.

\section{Abbreviations}

GC-MS: Gas chromatography-mass spectrometry; MIC: Minimum inhibitory concentration; MBC: Minimum bactericidal concentration; ANOVA: Analysis of variance; SEM: Standard error of mean; NZI: No zone of inhibition.

\section{Acknowledgements}

The authors acknowledge Prof (Mrs) F. M. Ogbe for identifying the plant and the department of Biological Sciences, College of Basic and Applied Sciences, Samuel Adegboyega University, Ogwa, Edo State Nigeria, for providing a conducive environment for the research.

\section{Authors' contributions}

KEE conceived the research, designed the experiment and prepared the manuscript; FHA and JOE did the literature search, sampling, and data analysis. All authors have read and approved the manuscript.

\section{Funding}

Not applicable.

\section{Availability of data and materials}

Not applicable.

\section{Declarations}

Ethics approval and consent to participate

Not applicable.

\section{Consent for publication}

Not applicable.

\section{Competing interests}

There are no competing interests, financial and otherwise, between the authors.

\section{Author details}

${ }^{1}$ Department of Biological Sciences, College of Basic and Applied Sciences, Samuel Adegboyega University, Km 1, Ogwa - Ehor Road, PMB. 001, Ogwa, Edo State, Nigeria. ${ }^{2}$ IKS Research Group, Department of Pharmacology, Faculty of Health Sciences, University of the Free State, Bloemfontein 9301, Free State,
South Africa. ${ }^{3}$ Phytomedicine Unit, Department of Plant Biology and Biotechnology, University of Benin, PMB 1154, Benin City, Nigeria.

Received: 7 July 2021 Accepted: 16 October 2021

Published online: 29 October 2021

\section{References}

Abalaka ME, Daniyan SY, Oyeleke SB, Adeyemo SO (2012) The antibacterial evaluation of Moringa Oleifera leaf extracts on selected bacterial pathogens. J Microbiol Res 2(2):1-4

Abd El-Hack ME, Alagawany M, Elrys AS, Desoky EM, Tolba MN, Elnahal SM, Elnesr SS, Swelum AA (2018) Effect of forage Moringa oleifera L. (moringa) on animal health and nutrition and its beneficial applications in soil, plants and water purification. J Agric 8:8-22

Adetitun DO, Araoye HK, Akinyanju JA, Anibijuwon II (2013) The antimicrobial effects of the leaf extracts of Moringa oleifera on selected clinical bacterial isolates. Agrosearch 13(1):95-113

Adeyemi S, Larayetan R, Onoja AD, Ajayi A, Yahaya A, Ogunmola OO, Adeyi AO, Chijioke O (2021) Anti-hemorrhagic activity of ethanol extracts of Moringa oleifera leaf on envenomed albino rats. Sci African 12:1-10. https://doi.org/10.1016/j.sciaf.2021.e00742

Ajayi AO, Fadeyi TE (2015) Antimicrobial activities and phytochemical analysis of Moringa oleifera leaves on Staphylococcus aureus and Streptococcus species. Am J Phytomed Clin Therap 3(10):643-653

Akintelu MT, Amoo IA (2017) Evaluation of fatty acid, amino acid and phytochemical composites of raw and boiled milk bush seed (Thevetia peruviana). Samuel Adegboyega Univ Sci Technol J 2(1):31-39

Alhakmni F, Kumar S, Khan SA (2013) Estimation of total phenolic content in-vitro antioxidant and anti-inflammatory activity of flowers of Moringa oleifera. Asian Pac J Trop Biomed 3(8):623-627. https://doi.org/10. 1016/S2221-1691(13)60126-4

Association of Official Analytical Chemistry (2005) Official method of analysis. Association of official analytical chemist, Washington DC, USA

Atef NM, Shanab SM, Negm SI (2019) Evaluation of the antimicrobial activity of some plants extracts against antibiotic susceptible and resistant bacterial strains causing wound infection. Bull Natl Res Centre 43(144):154. https://doi.org/10.1186/s42269-0190184-09

Azwanida NN (2015) A review on the extraction methods use in medicinal plants, principle, strength and limitation. Med Aromatic Plants 4:196

Balamurugan V, Balakrishnan V, Sundaresan A (2015) GC-MS analysis of leaf and Bark Extract of Moringa concanensis Nimmo, a siddha medicinal plant of South India. Eur J Biotechnol Biosci 3(12):57-61

Bukar A, Uba A, Oyeyi TI (2010) Antimicrobial profile of moringa oleifera lam. Extracts against some food-borne microorganisms. Bayero J Pure Appl Sci 3(1): 43-48

Chandrasekaran M, Senthilkumar A, Venkatesalu V (2011) Antibacterial and antifungal efficacy of fatty acid methyl esters from the leaves of Sesuvium portulacastrum L. Eur Rev Med Pharmacol Sci 15(7):775-780

Deeba F, Abbas N, Butt T, Imtiaz N, Khan RA, Ahsan MM (2015) Utilization of Moringa oleifera seeds for treatment of canal and industrial waste water-an alternative sustainable solution for developing countries. J Biodiversity Environ Sci 7:54-60

Enerijiofi KE, Isola OB (2019) Preliminary Phytochemical screening and in-vitro antibacterial activities of aqueous and ethanol extracts of Ageratum conyzoides L. Leaf, Stem, Flower and Root on some Bacterial isolates associated with Diarrhoea. Niger J Pure Appl Sci 32(2): 3480-3489. Doi:https://doi.org/10.19240/njpas.2019.B09

Erhabor JO, Oshomoh EO, Enerijiofi KE, Erhabor CR, Ogbonnaya CS, Idu M (2017) Antibacterial activity and phytochemical screening of the acetone extracts of the root of Aloe vera (L.) Burm. F. against microorganisms associated with male infertility. Samuel Adegboyega Univ Sci Technol J 2 (1): 7-16

Fapohunda SO, Mmom JU, Fakeye F (2012) Proximate analyses, phytochemical screening and antibacterial potentials of bitter cola, cinnamon, ginger and banana peel. Acad Arena 8:8-15 
Farooq F, Rai M, Tiwari A, Farooq S, Khan A (2012) Medicinal properties of Moringa oleifera: an overview of promising healer. J Med Plants Res 6(27):4368-4374

Gandji K, Chadare FJ, Idohou R, Salako VK, Assogbadjo AE, Glele Kakai RL (2018) Status and utilization of Moringa oleifera Lam: a review. Afr Crop Sci J 26(1):137-156

Husni E, Badriyya E, Putri L, Aldi Y (2021) The effect of ethanol extracts of Moringa leaf (Moringa oleifera Lam) against the activity and capacity of phagocytosis of macroflag cells and the percentage of leukosit cells of white mice Pharmacognosis J 13(3): 706-712. https://di.org/https://doi. org/10.5530/pj2021.13.90

Jaddoa HH, Hameed IH, Mohammed GJ (2016) Analysis of volatile metabolites released by Staphylococcus aureus using gas chromatography-Mass spectrometry and determination of its antifungal activity. Orient J Chem 32(4):8-24

Jaiswal D, Rai PK, Mehta S, Chatterji S, Shukla S, Rai DK, Watal G (2013) Role of Moringa oleifera in the regulation of diabetes-induced oxidative stress. Asian Pac J Trop Med 6:426-432

Mangale SM, Chonde SG, Raut PD (2012) Use of Moringa oleifera (Drumstick) seed as Natural Absorbent and an Antimicrobial agent for Groundwater Treatment. Res J Recent Sci 1(3):31-40

Mikore D, Mulugeta E (2017) Determination of proximate and mineral compositions of Moringa oleifera and Moringa stenopetala leaves cultivated in Arbaminch Zuria and Konso. Ethiopia Afr J Biotechnol 16(15):808-818. https://doi.org/10.5897/AJB2017.15919

Moyo B, Masika PJ, Muchenje V (2012) Antimicrobial activities of Moringa oleifera Lam. Leaf Extracts. Afr J Biotechnol 11:2797-2802

Mujeeb F, Bajpai P, Pathak N (2014) Phytochemical evaluation, antimicrobial activity, and determination of bioactive components from leaves of Aegle marmelos. Biomed Res Int 14:1-11. https://doi.org/10.1155/2014/497606

Nigussie D, Davery G, Legesse BA, Fekadu A, Mkonnen E (2021) Antimicrobial activity of methanol extracts of leaves of three medicinal plants against selected bacteria isolated from wounds of lymphedema patients. BMC Complimentary Med Ther 21: 2-11. https://doi.org/10.1186/ s12906-020-03183-0

Ogbeibu AE (2005) Biostatistics: a practical approach to research and data handling. Mindex Publishing Company Limited, Benin City, p 264
Othman L, Sleiman A, Abdel-Massih RM (2019) Activity of polyphenols and alkaloids in middle eastern plants. Front Microbiol. https://doi.org/10. 3389/fmicb.2019.00911

Oyama MO, Egbebi AO, Akharaiyi FC (2019) Phytochemical analysis and antibacterial activities of some plant extracts on Staphylococcus aureus isolates from patients receiving hospital treatments in Ekiti State, Nigeria. J Herbal Med Pharmacol 8(1):14-20

Singa NI, Hanafi M, Yantih N (2021) Identification of chemical compounds and antibacterial activity of $96 \%$ ethanol extract from Moringa oleifera LAM leaves against methicillin-resistant Staphylococcus aureus. Int J Appl Pharmaceutics 13(2):111-114

Sivakumar R, Jebanesan A, Govindarajan M, Rajasekar P (2011) Larvicidal and repellent activity of tetradecanoic acid against Aedes aegypti (Linn.) and Culex quinquefasciatus (Say.)(Diptera: Culicidae). Asian Pac J Trop Med 4(9):706-710

Teixeira EMB, Carvalho MRB, Neves VA, Silva MA, Arantes- Pereira L (2014) Chemical characteristics and fractionation of proteins from Moringa oleifera Lam. Leaves Food Chem 147:51-54

Unuigbe CA, Okeri HA, Erharuyi O, Oghenero EE, Obamedo DA (2014) Phytochemical and antioxidant evaluation of Moringa oleifera (Moringaceae) leaf and seed. J Pharmacol Bioresour 11(2):51-57

Vongsak B, Sithisarn P, Mangmool S, Thongpraditchote S (2013) Maximizing total phenolics, total flavonoids contents and antioxidant activity of Moringa oleifera leaf extract by the appropriate extraction method. Ind Crops Prod J 44:566-571

Zaku SG, Emmanuel S, Tukur AA, Kabir A (2015) Moringa oleifera: an underutilized tree in Nigeria with amazing versatility: a review. Afr J Food Sci $9(9): 456-461$

Zhang Z, Chen M, Yu Y, Pan S, Liu Y (2018) Antimicrobial susceptibility among gram-positive and gram-negative bloodborne pathogens collected between 2012 and 2016 as part of tigecycline and surveillance trial. Antimicrob Resist Infect Control 7(152):43-48

\section{Publisher's Note}

Springer Nature remains neutral with regard to jurisdictional claims in published maps and institutional affiliations.

\section{Submit your manuscript to a SpringerOpen ${ }^{\circ}$ journal and benefit from:}

- Convenient online submission

- Rigorous peer review

- Open access: articles freely available online

- High visibility within the field

- Retaining the copyright to your article

Submit your next manuscript at springeropen.com 